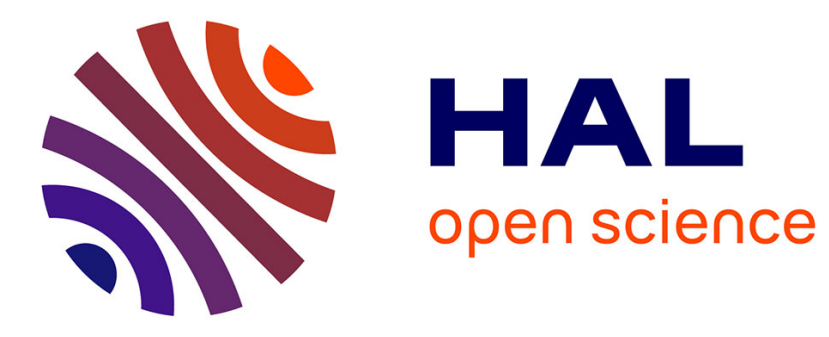

\title{
Energetics of lanthanide-doped calcium phosphate apatite
}

Seyedeh Mahboobeh Hosseini, Christophe Drouet, Ahmed Al-Kattan, Alexandra Navrotsky

\section{- To cite this version:}

Seyedeh Mahboobeh Hosseini, Christophe Drouet, Ahmed Al-Kattan, Alexandra Navrotsky. Energetics of lanthanide-doped calcium phosphate apatite. American Mineralogist, 2014, vol. $99\left(\mathrm{n}^{\circ} 11-12\right)$, pp. 2320-2327. 10.2138/am-2014-4930 . hal-01194786

\section{HAL Id: hal-01194786 \\ https://hal.science/hal-01194786}

Submitted on 7 Sep 2015

HAL is a multi-disciplinary open access archive for the deposit and dissemination of scientific research documents, whether they are published or not. The documents may come from teaching and research institutions in France or abroad, or from public or private research centers.
L'archive ouverte pluridisciplinaire HAL, est destinée au dépôt et à la diffusion de documents scientifiques de niveau recherche, publiés ou non, émanant des établissements d'enseignement et de recherche français ou étrangers, des laboratoires publics ou privés. 


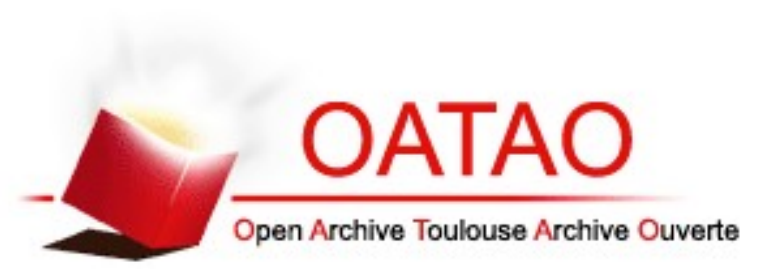

\section{Open Archive TOULOUSE Archive Ouverte (OATAO)}

OATAO is an open access repository that collects the work of Toulouse researchers and makes it freely available over the web where possible.

This is an author-deposited version published in : http://oatao.univ-toulouse.fr/ Eprints ID : 14230

To link to this article : DOI:10.2138/am-2014-4930

URL : http://dx.doi.org/10.2138/am-2014-4930

To cite this version : Mahboobeh Hosseini, Seyedeh and Drouet, Christophe and Al-Kattan, Ahmed and Navrotsky, Alexandra Energetics of lanthanide-doped calcium phosphate apatite. (2014) American Mineralogist, vol. 99 (n 11-12). pp. 2320-2327. ISSN 0003-004X

Any correspondance concerning this service should be sent to the repository administrator: staff-oatao@listes-diff.inp-toulouse.fr 


\title{
Energetics of lanthanide-doped calcium phosphate apatite
}

\author{
S. Mahboobeh Hosseini ${ }^{1,2}$, Christophe Drouet ${ }^{3}$, AhMed Al-Kattan $^{3}$ \\ AND ALEXANDRA NAVROTSKY ${ }^{1,2, *}$
}

\begin{abstract}
${ }^{1}$ Peter A Rock Thermochemistry Laboratory and NEAT ORU, University of California Davis, One Shields Avenue, Davis, California 95616, U.S.A ${ }^{2}$ Department of Chemical Engineering and Materials Science, University of California Davis, One Shields Avenue, Davis, California 95616, U.S.A. ${ }^{3}$ CIRIMAT Carnot Institute_Phosphates, Pharmacotechnics, Biomaterials Group, UMR CNRS/INPT/UPS 5085, University of Toulouse, 4 allée Emile Monso, 31030 Toulouse, France
\end{abstract}

\begin{abstract}
Lanthanides "Ln" (rare earths) are critical elements found in natural minerals such as calcium phosphate apatites, in sedimentary and igneous settings as well as in skeletal diagenesis. From a medical point of view, nanoparticles of lanthanide-doped apatites can be produced for conferring luminescence properties of interest in cancer cells detection. However, the impact of the substitution of $\mathrm{Ln}$ for $\mathrm{Ca}$ on the stability and solubility of related apatite phases is still essentially unknown. To investigate the thermochemical effects of such lanthanide substitution for calcium in apatite, we prepared and analyzed four series of apatites with up to $10 \%$ lanthanide substitution for calcium. After thorough physicochemical characterization via complementary techniques (XRD, FTIR, TG/DSC, and IPCAES), high-temperature oxide melt solution calorimetry in molten sodium molybdate at $973 \mathrm{~K}$ was performed to determine their enthalpies of formation from constituent oxides and from the elements, at $298 \mathrm{~K}$. Our results indicate that although enthalpies of formation are strongly exothermic in all cases, Ln-doping has a destabilizing effect, which increases with dopant concentration and with the size of the incorporated $\mathrm{Ln}^{3+}$ ion. After estimating standard entropies, Gibbs free energies of formation and equilibrium constants for $\mathrm{Ca}^{2+} / \mathrm{Ln}^{3+}$ exchange reactions in apatite were then evaluated, for the first time allowing access to quantitative thermodynamic data that may be used in various fields for stability calculations or partitioning estimates between fluids and solids.
\end{abstract}

Keywords: Calcium phosphate hydroxyapatite; lanthanide substitution; enthalpy of formation; calorimetry

\section{INTRODUCTION}

Apatites, corresponding to the general chemical formula $\mathrm{M}_{10}\left(\mathrm{TO}_{4}\right)_{6} \mathrm{X}_{2}$, represent a large family of minerals commonly found in nature as both geological materials and biominerals in calcified tissues. In this versatile structure, $\mathrm{M}$ is often a divalent cation (e.g., $\mathrm{Ca}^{2+}, \mathrm{Sr}^{2+}$, and $\mathrm{Pb}^{2+}$ ), $\mathrm{TO}_{4}$ is an anionic group (e.g., $\mathrm{PO}_{4}^{3-}, \mathrm{SiO}_{4}^{2-}$, and $\mathrm{VO}_{4}^{3-}$ ), and $\mathrm{X}$ is usually a monovalent anion (e.g., $\mathrm{F}^{-}, \mathrm{OH}^{-}$, and $\mathrm{Cl}^{-}$), although ions exhibiting other valences (e.g., $\mathrm{CO}_{3}^{2-}, \mathrm{HPO}_{4}^{2-}, \mathrm{O}^{2-}, \mathrm{Na}^{+}$) may also be incorporated (Elliott 1994).

Calcium phosphate hydroxyapatite $\left[\mathrm{Ca}_{10}\left(\mathrm{PO}_{4}\right)_{6}(\mathrm{OH})_{2}\right], \mathrm{HA}$, is one of the most common apatite end-members. It is produced, with varying degrees of stoichiometry, by vertebrates for ensuring physico-chemical as well as mechanical functions of hard tissues (Gomez-Morales et al. 2013) and is also encountered in many other contexts including in the geochemistry, anthropology, and biomaterials fields (Kohn et al. 2003; Bohner et al. 2008; Grunenwald et al. 2014; Prabakaran et al. 2005; Rabadjieva et al. 2010; Rodriguez-Lorenzo and Gross 2003; Verron et al. 2010). Apatite with substantial fluorine substitution for hydroxyl (fluorapatite) occurs in both sedimentary and igneous settings, sometimes as massive deposits, which are mined as a source

* E-mail: anavrotsky@ucdavis.edu of phosphate for fertilizer, but that are also potential sources of the lanthanides (aka rare earths), which are considered critical elements for technology (Nagasawa 1970; Reynard et al. 1999; Spear and Pyle 2002). In the paleoanthropology domain, the analysis of skeletal remains has also pointed out the occurrence of lanthanides associated to the apatitic phase during bone/teeth diagenesis (Tutken et al. 2011; Kocsis et al. 2010; Trueman and Tuross 2002). The study of $\mathrm{Ln}$ incorporation in apatites can also help modeling the incorporation of radioactive actinide elements, which are more complex to handle (Martin et al. 1999). Since it is compositionally and structurally close to the inorganic component of bones and teeth, hydroxyapatite is both biocompatible and bioactive, especially in nanocrystalline and nonstoichiometric form (Drouet et al. 2005; Eichert et al. 2005; Elliott 1994; Rey et al. 2007a, 2007b; Verron et al. 2010). Calcium phosphate apatite-based systems have therefore captivated the attention of biotechnology engineers for decades, and its use is now widespread in bone filling, prosthesis coating, and related applications (Cardoso et al. 2012; Rey et al. 2011). The last decades have produced numerous biomaterials based on apatite, sometimes associated with drugs or biologically active ions (AlKattan et al. 2010b; Barroug and Glimcher 2002; Benaziz et al. 2001; Bohner et al. 2008; Drouet et al. 2008, 2012; Iafisco et al. 2012; Weber et al. 2013). Biomimetic apatite-based hybrid 
systems have been used in cancer diagnosis and therapeutics (Al-Kattan et al. 2010a, 2011, 2010b, 2012; Bouladjine et al. 2009; Mondejar et al. 2007; Yang et al. 2008).

Despite this broad interest in apatites, structural, and energetic studies relating to the incorporation of lanthanides into apatite remain infrequent. There remains a lack of understanding of the thermodynamics of formation of apatite compounds that may exhibit various degrees of stoichiometry, crystallinity, particle size, and ionic substitution. Published data almost invariably addresses only well-crystallized stoichiometric apatites (Jemal 2011) (e.g., hydroxyapatite, fluorapatite, and apatites doped with heavy metals or alkaline earth ions), and the thermodynamic effects of lanthanide incorporation into phosphate apatites $\mathrm{M}_{10}\left(\mathrm{PO}_{4}\right)_{6} \mathrm{X}_{2}$ do not seem to have been specifically addressed. In a recent study (Rollin-Martinet et al. 2013), we investigated by solution calorimetry the energetics of biomimetic apatites corresponding to various stoichiometries, documenting in particular their strongly negative enthalpy-driven Gibbs free energies of formation, and we related the formation energetics to changes in calcium and hydroxide contents, unveiling the importance of ionic substitution on apatite thermodynamics.

The aim of the current work is to explore the formation energetics of calcium phosphate hydroxyapatite obtained in wet conditions and doped by lanthanide $\left(\mathrm{Ln}^{3+}\right)$ ions, namely europium, erbium, neodymium, and terbium.

\section{EXPERIMENTAL METHODS}

\section{Sample synthesis and characterization}

Ln-doped calcium phosphate hydroxyapatite samples $(\mathrm{Ln}=\mathrm{Eu}, \mathrm{Er}, \mathrm{Nd}$, or $\mathrm{Tb})$ were prepared by co-precipitation. Initial $\mathrm{Ln} /(\mathrm{Ln}+\mathrm{Ca})$ molar ratios ranging between 0 and $0.10(=10 \%)$ were used. For each preparation, two starting solutions were prepared using deionized water. Solution A contained the proper amounts of $\mathrm{Ca}\left(\mathrm{NO}_{3}\right)_{2} \cdot 4 \mathrm{H}_{2} \mathrm{O}$ (Merck, Emsure) and $\mathrm{Ln}\left(\mathrm{NO}_{3}\right)_{3} \cdot \mathrm{nH}_{2} \mathrm{O}$ (Prolabo, analytical grade), and solution $\mathrm{B}$ contained the appropriate amount of $\left(\mathrm{NH}_{4}\right)_{2} \mathrm{HPO}_{4}$ (Prolabo, analytical grade). In a typical experiment, $12.5 \mathrm{~mL}$ of solution $\mathrm{A}$ (total initial $\mathrm{Ca}+\mathrm{Ln}$ concentration: $0.4 \mathrm{M}$ ) was mixed with $12.5 \mathrm{~mL}$ of solution $\mathrm{B}$ (initial phosphate concentration: $0.13 \mathrm{M}$ ), at room temperature and under stirring for $30 \mathrm{~min}$. The initial $\mathrm{pH}$ was set to 9.5 by addition of $20 \%$ ammonia (Fisher Scientific) under $\mathrm{pH}$ electrode control. The precipitate obtained after mixing was allowed to mature in an oven at $373 \mathrm{~K}$ for $16 \mathrm{~h}$. The obtained suspension was then washed 6 times with deionized water using ultracentrifugation at $12500 \mathrm{rpm}$ to eliminate unreacted salts and undesired counter-ions. The purified suspensions were freeze-dried at $215 \mathrm{~K}$ for 3 days. The obtained powder samples are denoted "CaLnPx" where $\mathrm{x}$ represents the initial $\mathrm{Ln} /(\mathrm{Ca}+\mathrm{Ln})$ molar ratio. For example, "CaEuP7" represents the sample precipitated in the presence of $7 \%$ of europium relative to the total $\mathrm{Ca}+\mathrm{Ln}$ content.

$\mathrm{Eu}(\mathrm{OH})_{3}$ was synthesized by precipitation in alkaline medium, using a mixture of europium nitrate and a few drops of concentrated $\mathrm{NaOH}$ (VWR, analytical grade). The europium nitrate was dissolved in deionized water and the solution was stirred for $5 \mathrm{~min}$. Then, $\mathrm{NaOH}$ was slowly added dropwise until precipitation, and the medium was heated at $90^{\circ} \mathrm{C}$ overnight under constant stirring. The precipitate was centrifuged and washed 6 times with deionized water to remove residual ions. The final product was then oven-dried at $50{ }^{\circ} \mathrm{C}$. This material was used for thermochemical measurements, as shown below.

Phase identification was carried out by powder X-ray diffraction (XRD) on a Bruker AXS D8 Advance diffractometer using $\mathrm{CuK \alpha _{1 }}$ radiation $(\lambda=1.5406 \AA)$, using a beam voltage of $40 \mathrm{kV}$ and an emission current of $40 \mathrm{~mA}$. A $0.02^{\circ}$ step size from 10 to $90^{\circ} 2 \theta$ with a $2 \mathrm{~s} / \mathrm{step}$ dwell time was used as an acquisition parameter. MDI Jade software was used to identify the phases.

The presence of possible impurities, such as nitrate ions, was examined by Fourier transform infrared spectroscopy (FTIR) using $\mathrm{KBr}$ as a solid diluent, in the wavenumber range $400-4000 \mathrm{~cm}^{-1}$ (resolution $4 \mathrm{~cm}^{-1}$ ), on a Nicolet 5700 spectrometer.

The Ca, P, Eu, Tb, Er, and Nd contents were measured at Marion Technolo- gies S.A. (France) by inductively coupled plasma atomic emission spectroscopy, ICP-AES, with a relative uncertainty of 3\%, using a Jobin Yvon apparatus (JY2000 model), after preliminary elemental calibrations (Chem-Lab reagents). Each measurement was performed starting from a volume of $50 \mathrm{~mL}$ of solution obtained by dissolving $10-15 \mathrm{mg}$ of powdered sample in concentrated $\mathrm{HCl}$, and followed by a fivefold dilution. The following wavelengths were considered for the elemental titrations: $393.366 / 422.673 \mathrm{~nm}$ for $\mathrm{Ca} ; 213.618 / 214.914 \mathrm{~nm}$ for $\mathrm{P} ; 381.966 \mathrm{~nm}$ for $\mathrm{Eu}$; 350.917 and $367.635 \mathrm{~nm}$ for Tb; $337.271 / 381.966 \mathrm{~nm}$ for Er and 406.109/430.357 $\mathrm{nm}$ for $\mathrm{Nd}$. Tests were made in duplicate.

Differential scanning calorimetry (DSC) coupled with thermogravimetric analysis (TG) was performed on a Netzsch STA 449 at $25-1000{ }^{\circ} \mathrm{C}$ to measure the water content and follow potential phase transition/decomposition for each sample. About $25 \mathrm{mg}$ of compound was pelletized for each test. The sample was heated at $10{ }^{\circ} \mathrm{C} / \mathrm{min}$ under synthetic air at a flow rate of $40 \mathrm{~mL} / \mathrm{min}$. Two runs were performed for each sample.

\section{High-temperature oxide melt solution calorimetry}

Calorimetric experiments were carried out in a custom-built Tian-Calvet twin microcalorimeter. The equipment and experimental procedures have been described in detail by Navrotsky (Navrotsky 1977, 1997). Calibration of the calorimeter was based on the known heat content of $\sim 5 \mathrm{mg} \alpha-\mathrm{Al}_{2} \mathrm{O}_{3}$ pellets. The methodology was identical to that used in our recent study on biomimetic apatites (Rollin-Martinet et al. 2013).

Prior to drop solution calorimetry, the samples were hand-pressed into pellets $(\sim 5 \mathrm{mg})$, and weighed on a microbalance. The calorimetric experiments were performed by dropping the pellets, one by one, from room temperature $\left(25^{\circ} \mathrm{C}\right)$ into molten sodium molybdate solvent $\left(3 \mathrm{Na}_{2} \mathrm{O} \cdot 4 \mathrm{MoO}_{3}\right)$ at $700{ }^{\circ} \mathrm{C}$ in the calorimeter. The measured heat effect, called the enthalpy of drop solution, $\Delta \mathrm{H}_{\mathrm{ds}}$, is equal to the sum of the heat content of the sample, $\int_{25}^{700} \mathrm{CpdT}$, and the heat of sample dissolution in sodium molybdate at $700{ }^{\circ} \mathrm{C}$. During calorimetry, air was flushed through the calorimetric glassware assembly at $70 \mathrm{~mL} / \mathrm{min}$ to expel any gases (e.g., water vapor) evolved in the calorimeter. Air was also bubbled through the solvent at 5 $\mathrm{mL} / \mathrm{min}$ to facilitate the dissolution of the sample and thus avoid local solvent saturation. Complete dissolution of the sample in the solvent was verified during preliminary furnace experiments. At least 8 measurements were made for each sample. Two standard deviations of the mean are considered for evaluating the uncertainty of the data.

\section{RESULTS AND DISCUSSION}

\section{Sample characterization}

The samples precipitated in the presence of lanthanide ions $\left(\mathrm{Eu}^{3+}, \mathrm{Er}^{3+}, \mathrm{Nd}^{3+}\right.$, or $\left.\mathrm{Tb}^{3+}\right)$ with initial $\mathrm{Ln} /(\mathrm{Ln}+\mathrm{Ca})$ molar ratios of $0,0.01,0.02,0.04,0.07$, and 0.10 were first analyzed by XRD for phase identification. In each case, the diffraction pattern showed the main characteristic peaks of an HA-like phase, thus confirming the formation of an apatitic compound. Typical XRD patterns obtained for the Eu series are shown in Figure 1, where the apatite phase has been indexed with respect to the JCPDS reference hydroxyapatite file no. 09-432. Upon increasing the initial amount of lanthanide in the initial mixture, however, the presence of a secondary phase-identified as the corresponding lanthanide hydroxide $\mathrm{Ln}(\mathrm{OH})_{3}$-was also detected, and the relative proportions of apatite and lanthanide hydroxide were evaluated (see below).

The synthesis protocol used in this work was specifically selected because it is identical to the one used previously for the preparation of Ln-doped colloidal apatite nanoparticles (Al-Kattan et al. 2010a, 2014). Because it involves an excess of cations $\left(\mathrm{Ca}^{2+}+\mathrm{Ln}^{3+}\right)$ over phosphate ions (relatively to the HA stoichiometry), as well as an alkaline $\mathrm{pH}$, the formation of $\mathrm{Ln}(\mathrm{OH})_{3}$ as a secondary phase for high Ln concentrations is not surprising. Limits to the amount of incorporated $\mathrm{Ln}^{3+}$ ions have indeed been shown (Al-Kattan et al. 2010a). Note that in 


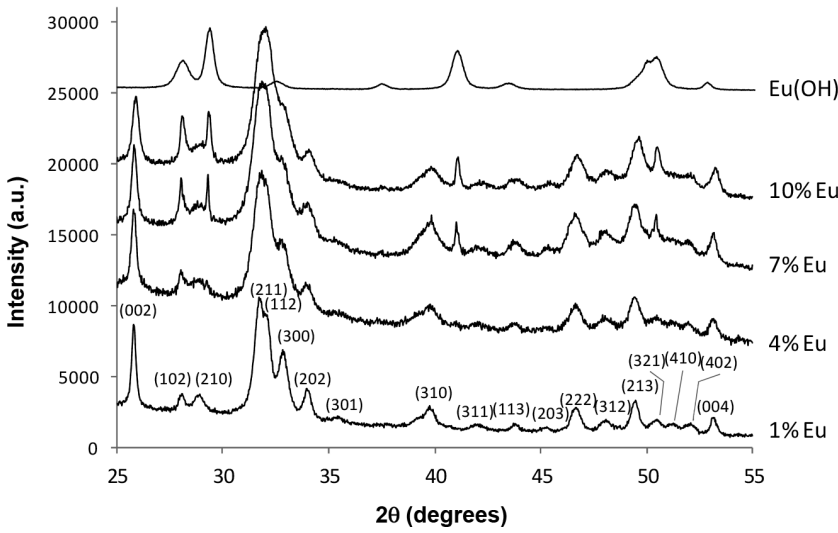

$\triangle$ FIGURE 1. XRD patterns obtained for increasing $\mathrm{Ln}^{3+}$ content: typical case of the europium doping series, with indexation according to the JCPDS no. 09-432 card. Inset: zoom on (002) diffraction peak.

the present study the presence of lanthanide phosphate $\mathrm{LnPO}_{4}$ was never detected, which was also expected from our synthesis conditions (low phosphate content).

FTIR spectroscopy was used to characterize the precipitated samples. Very similar spectra were obtained for all samples. The vibrational data were found to support the XRD results in that the main vibration bands of a calcium phosphate apatite phase were detected in each sample. Figure 2 reports the typical case of Eu-doped samples. The presence of trace hydroxide ions in a secondary environment [i.e., within a $\mathrm{Ln}(\mathrm{OH})_{3}$ lattice] was not detected by FTIR, which may be linked to the concomitant presence of hydration water molecules that give rise to a broad covering $\mathrm{O}-\mathrm{H}$ vibration band around $3500 \mathrm{~cm}^{-1}$.

Taking into account the XRD and FTIR findings, the prepared compounds are thus found to be composed of lanthanide-doped apatite associated to a secondary phase of lanthanide hydroxide

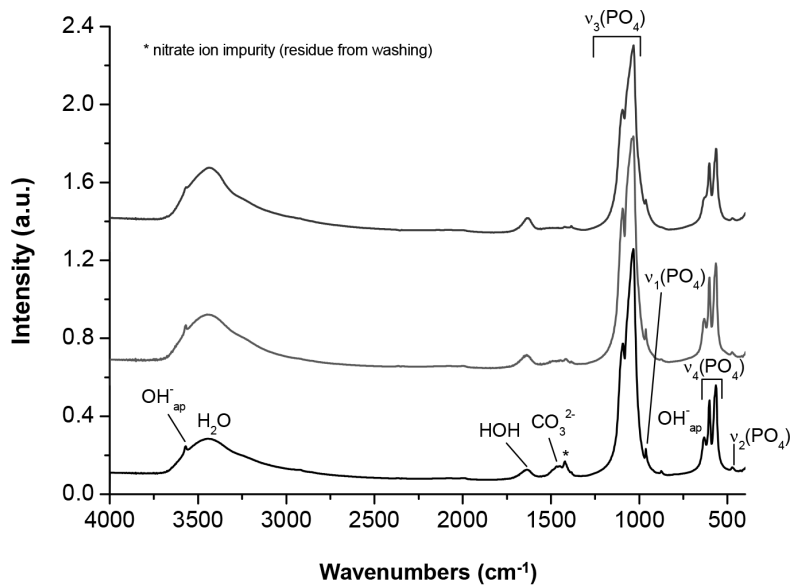

FIGURE 2. FTIR spectra for increasing $\mathrm{Ln}^{3+}$ content: typical case of the europium doping series $(0,2$, and $7 \mathrm{~mol} \% \mathrm{Eu}$ initial).
Zoom on (002) peak

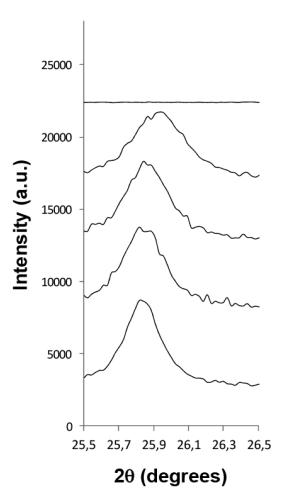

for high initial dopant amounts. Before further investigating the chemical composition of the samples, a question arises concerning the type of substitution mechanism for trivalent $\mathrm{Ln}^{3+}$ ions replacing divalent $\mathrm{Ca}^{2+}$ in the apatite lattice. Indeed, lanthanide incorporation can a priori occur by different substitution mechanisms. In the absence of monovalent cations (e.g., $\mathrm{Na}^{+}$) or tetravalent anions (e.g., $\left.\mathrm{SiO}_{4}^{4}\right)$, four distinct substitution mechanisms can be envisioned (Al-Kattan et al. 2010a) for apatites obtained by wet chemistry (see Table 1).

If one hypothesizes that any of these four mechanisms, or a combination of them, is possible for the incorporation of trivalent lanthanide ions into the apatite structure, it should be possible to calculate the stoichiometry of each sample according to its $\mathrm{Ln}^{3+} / \mathrm{Ca}^{2+}$ ratio and the specific substitution mechanism of interest. By applying the four model mechanisms independently to each sample, it appears that at low dopant concentrations $(\mathrm{y} \leq 0.02)$ all four mechanisms are possible. However, results from ICP-AES indicate that at high lanthanide concentrations, only mechanism 4 remains possible, since the other model mechanisms would result in negative values for the $\mathrm{HPO}_{4}^{2-}$ or $\mathrm{OH}^{-}$contents. This mechanism implies, upon Ca-for-Ln substitution, the concomitant deprotonation of some $\mathrm{OH}^{-}$ions giving rise to $\mathrm{O}^{2-}$ anions in apatitic tunnels, which has already been reported in Ln-doped apatites (Taitai and Lacout 1987; Ternane et al. 1999). In such scenarios, the high strength of the Eu-O bonds may be seen as a stabilizing factor (Piriou et al. 1987; Ternane et al. 1999). The existence of oxyapatite or oxyhydroxyapatite phases (for which a single $\mathrm{O}^{2-}$ takes the place of two $\mathrm{OH}^{-}$in the apatite formula) is well accepted (Yamashita et al. 1986), and could also hold at moderate to low temperatures, taking into account the Eu-O bond strength mentioned above. Despite the moderate temperature $\left(100^{\circ} \mathrm{C}\right)$ used for synthesis in the present study, we appear to observe mechanism 4 , thus involving $\mathrm{O}^{2-}$ ions, at least for high $\mathrm{Ln}$ contents. Indeed, mechanism 4 is the only one to explain the experimental data for the whole series of samples prepared in this work and will be considered to be the leading substitution scheme. For low Ln contents, other mechanisms (or a combination of mechanisms) listed in Table 1 may also come into play to some extent but they are not possible to determine here.

Once one major type of substitution mechanism is assumed,

TABLE 1. Possible mechanisms for lanthanide $\left(\mathrm{Ln}^{3+}\right)$ doping in calcium phosphate hydroxyapatite (Al-Kattan et al. 2010a)

Mechanism 1 ${ }^{\mathrm{a}}$ :

$3 \mathrm{Ca}^{2+} \rightarrow 2 \mathrm{Ln}^{3+}+\square_{\mathrm{Ca}} \rightarrow \mathrm{Ca}_{10-\mathrm{x}-3 \mathrm{y} / 2} \mathrm{Ln}_{\mathrm{y}}\left(\square_{\mathrm{Ca}}\right)_{\mathrm{x}+\mathrm{y} / 2}\left(\mathrm{PO}_{4}\right)_{6-\mathrm{x}}\left(\mathrm{HPO}_{4}\right)_{\mathrm{x}}(\mathrm{OH})_{2-\mathrm{x}}\left(\square_{\mathrm{OH}}\right)_{x}$

Mechanism $2^{\text {b: }}$

$\mathrm{Ca}^{2+}+\mathrm{HPO}_{4}^{2-} \rightarrow 2 \mathrm{Ln}^{3+}+\mathrm{PO}_{4}^{3--} \rightarrow \mathrm{Ca}_{10-x-y} \mathrm{Ln}_{\mathrm{y}}\left(\square_{\mathrm{Ca}}\right)_{x}\left(\mathrm{PO}_{4}\right)_{6-\mathrm{x}+\mathrm{y}}\left(\mathrm{HPO}_{4}\right)_{\mathrm{x}-\mathrm{y}}(\mathrm{OH})_{2-\mathrm{x}}\left(\square_{\mathrm{OH}}\right)_{x}$

Mechanism 3c:

$\mathrm{Ca}^{2+}+\square_{\mathrm{OH}} \rightarrow \mathrm{Ln}^{3+}+\mathrm{OH}^{-} \rightarrow \mathrm{Ca}_{10-x-y} \mathrm{Ln}_{y}\left(\square_{\mathrm{Ca}_{\mathrm{x}}}\right)_{\mathrm{x}}\left(\mathrm{PO}_{4}\right)_{6-\mathrm{x}}\left(\mathrm{HPO}_{4}\right)_{\mathrm{x}}(\mathrm{OH})_{2-\mathrm{x}+\mathrm{y}}\left(\square_{\mathrm{OH}}\right)_{x-y}$

Mechanism $4^{\text {d. }}$

$\mathrm{Ca}^{2+}+\mathrm{OH}^{-} \rightarrow \mathrm{Ln}^{3+}+\mathrm{O}^{2-} \rightarrow \mathrm{Ca}_{10-x-y} \mathrm{Ln}_{y}\left(\square_{\mathrm{Ca}_{\mathrm{a}}}\right)_{\mathrm{x}}\left(\mathrm{PO}_{4}\right)_{6-\mathrm{x}}\left(\mathrm{HPO}_{4}\right)_{\mathrm{x}}(\mathrm{OH})_{2-\mathrm{x}-\mathrm{y}}(\mathrm{O})_{y}\left(\square_{\mathrm{OH}}\right)_{x}$

${ }^{a} x \leq 2 \cdot{ }^{b} x \leq 2 ; y \leq x \cdot{ }^{c} 0 \leq x-y \leq 2 ; y \leq x \cdot{ }^{d} x+y \leq 2$ 
TABLE 2. Overall compositions of the precipitated samples, as determined from ICP, TG/DSC and XRD data

\begin{tabular}{|c|c|c|c|c|c|c|c|c|c|}
\hline Sample & $\mathrm{Ca}^{2+}$ & $\mathrm{Ln}^{3+}$ & $\mathrm{PO}_{4}^{3-}$ & $\mathrm{HPO}_{4}^{2-}$ & $\mathrm{OH}^{-}$ & $\mathrm{O}^{2-}$ & $\mathrm{H}_{2} \mathrm{O}$ & $\mathrm{Ln}(\mathrm{OH})_{3}$ & $\begin{array}{c}\mathrm{Ln}^{3+} /\left(\mathrm{Ln}^{3+}\right. \\
\left.+\mathrm{Ca}^{2+}\right)^{\mathrm{a}}\end{array}$ \\
\hline $\mathrm{CaP}$ & 9.96 & 0.00 & 5.96 & 0.04 & 1.96 & 0.00 & 2.07 & 0.00 & 0.00 \\
\hline CaEuP1 & 9.62 & 0.18 & 5.79 & 0.21 & 1.62 & 0.18 & 2.16 & 0.00 & 0.02 \\
\hline CaEuP4 & 9.03 & 0.34 & 5.37 & 0.63 & 1.03 & 0.34 & 2.81 & 0.30 & 0.04 \\
\hline CaEuP7 & 8.36 & 0.55 & 4.91 & 1.09 & 0.36 & 0.55 & 4.52 & 0.55 & 0.06 \\
\hline CaEuP10 & 8.08 & 0.79 & 4.87 & 1.13 & 0.08 & 0.79 & 4.66 & 0.76 & 0.09 \\
\hline CaErP1 & 9.60 & 0.18 & 5.78 & 0.22 & 1.60 & 0.18 & 2.41 & 0.00 & 0.02 \\
\hline CaErP2 & 9.32 & 0.35 & 5.66 & 0.34 & 1.315 & 0.35 & 2.50 & 0.00 & 0.04 \\
\hline CaErP4 & 9.12 & 0.43 & 5.55 & 0.45 & 1.12 & 0.43 & 2.80 & 2.28 & 0.05 \\
\hline CaErP7 & 8.75 & 0.60 & 5.35 & 0.66 & 0.75 & 0.60 & 4.52 & 0.53 & 0.07 \\
\hline CaErP10 & 8.22 & 0.72 & 4.94 & 1.06 & 0.22 & 0.72 & 4.00 & 0.71 & 0.08 \\
\hline CaNdP1 & 9.52 & 0.19 & 5.71 & 0.29 & 1.52 & 0.19 & 1.86 & 0.00 & 0.02 \\
\hline CaNdP2 & 9.21 & 0.35 & 5.56 & 0.44 & 1.21 & 0.35 & 2.58 & 0.00 & 0.04 \\
\hline CaNdP7 & 8.54 & 0.46 & 5.00 & 1.00 & 0.54 & 0.46 & 4.40 & 0.55 & 0.05 \\
\hline CaNdP10 & 8.12 & 0.62 & 4.74 & 1.26 & 0.12 & 0.62 & 4.73 & 0.76 & 0.07 \\
\hline CaTbP2 & 9.24 & 0.36 & 5.60 & 0.40 & 1.24 & 0.36 & 2.77 & 0.00 & 0.04 \\
\hline CaTbP4 & 8.63 & 0.53 & 5.16 & 0.84 & 0.63 & 0.53 & 3.14 & 0.30 & 0.06 \\
\hline CaTbP7 & 8.55 & 0.90 & 5.45 & 0.55 & 0.55 & 0.90 & 4.39 & 0.57 & 0.09 \\
\hline CaTbP10 & 8.34 & 1.26 & 5.60 & 0.40 & 0.34 & 1.26 & 5.60 & 0.81 & 0.13 \\
\hline
\end{tabular}

Note: Mechanism 4 was applied, adapting the general formula: as $\mathrm{Ca}_{10-x-y}$ $\mathrm{Ln}_{\mathrm{y}}\left(\mathrm{PO}_{4}\right)_{6-x}\left(\mathrm{HPO}_{4}\right)_{x}(\mathrm{OH})_{2-x-y} \mathrm{O}_{\mathrm{y}} \cdot \mathrm{nH}_{2} \mathrm{O}$ and $\mathrm{Ln}=\mathrm{Eu}, \mathrm{Er}, \mathrm{Nd}$, and $\mathrm{Tb}(0 \leq \mathrm{y} \leq 0.10)$. a Experimental $\mathrm{Ln}^{3+} /\left(\mathrm{Ca}^{2+}+\mathrm{Ln}^{3+}\right)$ molar ratio in the corresponding apatite phase.

it becomes possible to define the chemical composition of the samples on the joint basis of ICP-AES, TG/DSC and XRD data. The numerical results obtained by considering mechanism 4 are reported in Table 2, per mole of doped apatite. In these calculations, as is customary for calcium phosphate apatites, the sum of the phosphates $\left(\mathrm{PO}_{4}^{3-}\right.$ and $\left.\mathrm{HPO}_{4}^{2-}\right)$ per mole of apatite was fixed at 6 . This assumes complete occupation of the phosphate crystallographic sites due to the large size of the orthophosphate ion and the presumed structural instability that would arise from phosphate vacancies. Once a $\mathrm{Ln} / \mathrm{Ca}$ substitution mechanism has been assumed (see Table 1), one has access to the chemical formula with two unknown parameters " $x$ " and " $y$ ". In the case of mechanism 4, for instance, we have: $\mathrm{Ca}_{10-\mathrm{x}-\mathrm{y}} \mathrm{Ln}_{\mathrm{y}}\left(\mathrm{PO}_{4}\right)_{6-\mathrm{x}}\left(\mathrm{HPO}_{4}\right)_{\mathrm{x}}$ $(\mathrm{OH})_{2-x-y}(\mathrm{O})_{\mathrm{y}}$. From ICP analyses, the $\mathrm{Ln} /(\mathrm{Ca}+\mathrm{Ln})$ as well as the $(\mathrm{Ca}+\mathrm{Ln}) / \mathrm{P}$ ratios were measured. Then, having two equations with two unknown parameters, we could straightforwardly solve this mathematical system and find " $\mathrm{x}$ " and " $\mathrm{y}$ ". This allowed the evaluation of the $\mathrm{PO}_{4}^{3-} / \mathrm{HPO}_{4}^{2-}$ speciation as well as the $\mathrm{OH}^{-} / \mathrm{O}^{2-}$ contents.

Based on Rietveld refinement of XRD data, the relative proportions of apatite and lanthanide hydroxide were concomitantly evaluated. TG/DSC measurements showed water loss (see also Rollin-Martinet et al. 2013) in the $25-212{ }^{\circ} \mathrm{C}$ range and the related weight loss permitted the evaluation of the amount of hydration water associated with the samples.

It may be noted (see final column of Table 2) that the experimental value of $\mathrm{Ln} /(\mathrm{Ca}+\mathrm{Ln})$ in the apatite phase increases when the initial dopant concentration increases, although this trend levels out for the highest Ln concentrations. This tendency toward constancy of the experimental Ln content is indicative of the existence of a maximal substitution limit, as may indeed be expected for such systems where trivalent cations replace divalent ones and where a second phase of $\operatorname{Ln}(\mathrm{OH})_{3}$ defines the solubility limit.

As indicated in Table 2, an increased $\mathrm{Ln}^{3+}$ ion concentration in Ca-sites is accompanied by a decrease in the total amount of $\left(\mathrm{O}^{2-}+\mathrm{OH}^{-}\right)$and an increase of both $\mathrm{HPO}_{4}^{2-}$ and water content.
Interestingly, a decrease in hydroxylation and an increase in $\mathrm{HPO}_{4}^{2-}$ were similarly observed for undoped nanocrystalline apatites of decreasing maturation states (Vandecandelaere et al. 2012). These findings suggest that lanthanide substitution decreases the overall degree of stoichiometry in the apatite phase. This suggests that $\mathrm{Ln}^{3+}$ ions play a role in apatite crystal growth inhibition, which is also the case of other ions such as $\mathrm{Mg}^{2+}$ or $\mathrm{Zn}^{2+}$ (Koutsoukos 1998). Such inhibitory effects are complex phenomena, where the mode of interaction of the metal ion with the solid phase comes into play, as well as crystallographic considerations (especially when a trivalent ion replaces a divalent one as is the case for $\mathrm{Ln}^{3+}$ ). Such a deviation from stoichiometry and decrease in degree of crystallinity are further confirmed in the present study on the basis of XRD data, where peak broadening was observed upon increasing Ln doping, thus pointing to a decrease in particle size that is in agreement with growth inhibition. This effect is, for example, visible on diffraction peak (002) (see inset in Fig. 1). The estimation of crystallite dimensions is delicate as peak width is not only dependent on particle size, but also on the presence of microstrains, which can be non-negligible for apatite compounds (Vandecandelaere et al. 2012). However, estimates of the mean crystallite length along the $c$-axis of the hexagonal unit cell have been tentatively calculated here using Scherrer's formula applied to the (002) peak, pointing out a decrease in mean crystallite length from ca. $40 \mathrm{~nm}$ down to about $25 \mathrm{~nm}$ when increasing the Ln content from 1 to $10 \%$.

According to the $\mathrm{XRD}$ results, a single apatite phase was observed only for low dopant concentrations (typically less than $y=0.04)$. Beyond this limit, as mentioned above, $\mathrm{Ln}(\mathrm{OH})_{3}$ formed as a secondary phase. However, the Ln incorporated amount continued to increase, thus indicating that the value of $y=0.04$ may be an underestimation of the real solubility limit of the $\mathrm{Ln}^{3+}$ ions in the apatitic lattice in our synthesis conditions. The concomitant presence of apatite and $\mathrm{Ln}(\mathrm{OH})_{3}$ phases may be related to not only thermodynamic but also kinetics aspects: the apatite phase being a complex oxide system with many ions to accommodate, its crystallization (especially if the incorporated ions act as growth inhibitors) requires time, allowing (at least in a transient way) secondary phases to be formed. In other words, our synthesis conditions do not allow complete equilibrium to be attained.

The composition of each sample, as listed in Table 2, was then taken into account in the energetic calculations below, so as to extract the enthalpy linked to the apatite phase alone.

\section{Calorimetric measurements and thermodynamic properties of Ln-doped apatites}

The experimental drop solution enthalpy $\left(\Delta H_{\mathrm{ds}}\right)$ values for the calcium phosphate apatite samples prepared here are listed in Table 3, as well as values for the constituent binary oxides and lanthanide hydroxides $\mathrm{Ln}(\mathrm{OH})_{3}$.

For samples containing a lanthanide hydroxide secondary phase (amount determined by XRD), the $\Delta H_{\mathrm{ds}}$ of the apatite phase was determined by correcting the measured $\Delta H_{\mathrm{ds}}$ for the two-component sample by the $\Delta H_{\mathrm{ds}}$ of the lanthanide hydroxide phase alone. Therefore, the enthalpies of drop solution of the $\mathrm{Ln}(\mathrm{OH})_{3}$ phases were also necessary to determine. As a starting 
TABLE 3. Enthalpies of drop solution $\left(\Delta H_{\mathrm{ds}}\right)$ of apatites, binary oxides, and lanthanide hydroxides in $3 \mathrm{Na}_{2} \mathrm{O} \cdot 4 \mathrm{MoO}_{3}$ at $973 \mathrm{~K}$, and enthalpies of formation at $298 \mathrm{~K}$ of apatites from constituent oxides $\left(\Delta H_{\mathrm{f}, \mathrm{ox}}^{\circ}\right)$ and from the elements taken in their standard state $\left(\Delta H_{\mathrm{f}, \mathrm{e}}^{\circ}\right)$

\begin{tabular}{|c|c|c|c|c|c|}
\hline Binary compounds & $\Delta H_{\mathrm{ds}}(\mathrm{kJ} / \mathrm{mol})$ & Apatite samples & $\Delta H_{\mathrm{ds}}(\mathrm{kJ} / \mathrm{mol})$ & $\Delta H_{\mathrm{f}, \mathrm{ox}}^{\circ}(\mathrm{kJ} / \mathrm{mol})$ & $\Delta H_{\mathrm{f}, \mathrm{el}}^{\mathrm{o}}(\mathrm{kJ} / \mathrm{mol})^{\mathrm{d}}$ \\
\hline $\mathrm{CaO}$ & $-90.70 \pm 1.69^{a}$ & $\mathrm{CaP}$ & $1102.21 \pm 8.94(8)^{\mathrm{b}}$ & $-2287.55 \pm 9.65$ & $-13307.5 \pm 12.4$ \\
\hline $\mathrm{P}_{2} \mathrm{O}_{5}$ & $-164.60 \pm 0.85^{a}$ & CaEuP1 & $1078.75 \pm 11.66(14)$ & $-2244.63 \pm 12.50$ & $-13173.1 \pm 14.9$ \\
\hline $\mathrm{H}_{2} \mathrm{O}$ & $69.00 \pm 1.00^{\mathrm{a}}$ & CaEuP4 & $1149.31 \pm 8.49(10)$ & $-2232.36 \pm 9.43$ & $-12894.1 \pm 12.7$ \\
\hline $\mathrm{Eu}_{2} \mathrm{O}_{3}$ & $-129.24 \pm 2.12^{\mathrm{a}}$ & CaEuP7 & $1176.13 \pm 10.75(10)$ & $-2101.71 \pm 11.25$ & $-12481.6 \pm 14.3$ \\
\hline $\mathrm{Er}_{2} \mathrm{O}_{3}$ & $-105.26 \pm 2.48^{a}$ & CaEuP10 & $1194.01 \pm 13.12(12)$ & $-2108.57 \pm 14.02$ & $-12474.7 \pm 16.8$ \\
\hline $\mathrm{Nd}_{2} \mathrm{O}_{3}$ & $-163.36 \pm 3.44^{a}$ & CaErP1 & $1099.34 \pm 12.02(10)$ & $-2247.75 \pm 12.50$ & $-13184.2 \pm 14.7$ \\
\hline $\mathrm{Tb}_{2} \mathrm{O}_{3}$ & $-125.58 \pm 2.40^{a}$ & CaErP2 & $1109.33 \pm 11.40(11)$ & $-2242.73 \pm 7.01$ & $-13139.1 \pm 10.5$ \\
\hline $\mathrm{Eu}(\mathrm{OH})_{3}$ & $115.70 \pm 1.27(8)$ & CaErP4 & $1139.68 \pm 11.42(12)$ & $-2205.22 \pm 9.43$ & $-13038.4 \pm 12.2$ \\
\hline $\mathrm{Eu}(\mathrm{OH})_{3}$ & $117.73 \pm 1.50^{c}$ & CaErP7 & $1177.09 \pm 15.77(12)$ & $-2146.12 \pm 11.25$ & $-12882.9 \pm 13.7$ \\
\hline $\mathrm{Er}(\mathrm{OH})_{3}$ & $99.40 \pm 1.80^{c}$ & CaErP10 & $1154.85 \pm 15.73(12)$ & $-2131.92 \pm 14.02$ & $-12627.4 \pm 16.0$ \\
\hline $\mathrm{Nd}(\mathrm{OH})_{3}$ & $194.00 \pm 2.40^{c}$ & CaNdP1 & $957.55 \pm 12.56(9)$ & $-2139.35 \pm 12.56$ & $-13024.5 \pm 14.8$ \\
\hline \multirow[t]{7}{*}{$\mathrm{Tb}(\mathrm{OH})_{3}$} & $-41.50 \pm 1.70^{c}$ & $\mathrm{CaNdP} 2$ & $1025.24 \pm 7.44(8)$ & $-2148.81 \pm 7.44$ & $-12958.9 \pm 10.8$ \\
\hline & & CaNdP7 & $1021.77 \pm 11.24(10)$ & $-1970.90 \pm 11.24$ & $-12439.3 \pm 13.6$ \\
\hline & & CaNdP10 & $1089.21 \pm 12.20$ & $-1936.32 \pm 12.20$ & $-12259.8 \pm 14.4$ \\
\hline & & CaTbP2 & $1041.67 \pm 6.17(8)$ & $-2178.21 \pm 7.01$ & $-13025.3 \pm 11.0$ \\
\hline & & $\mathrm{CaTbP} 4$ & $1070.18 \pm 6.90(8)$ & $-2152.35 \pm 9.43$ & $-12746.4 \pm 12.9$ \\
\hline & & CaTbP7 & $1145.46 \pm 13.44(10)$ & $-2130.41 \pm 11.25$ & $-12965.9 \pm 14.7$ \\
\hline & & CaTbP10 & $1205.79 \pm 11.36(8)$ & $-2122.98 \pm 14.02$ & $-13109.5 \pm 17.2$ \\
\hline
\end{tabular}

a From Ushakov et al. (2001).

b Uncertainty is two standard deviations of the mean. The number in parentheses is the number of experiments.

${ }^{c}$ Calculated by considering the reaction $\mathrm{Ln}(\mathrm{OH})_{3} \rightarrow 1 / 2 \mathrm{Ln}_{2} \mathrm{O}_{3}+3 / 2 \mathrm{H}_{2} \mathrm{O}$ and the known values of $\Delta H_{\mathrm{f}}^{\circ}($ hydroxide $), \Delta H_{\mathrm{f}}^{\circ}(\mathrm{oxide}), \Delta \mathrm{H}_{\mathrm{ds}}(\mathrm{oxide}), \Delta H_{\mathrm{hc}}\left(\mathrm{H}_{2} \mathrm{O}\right.$ gas, $\left.298-973 \mathrm{~K}\right)$ and $\Delta H_{f}^{o}\left(\mathrm{H}_{2} \mathrm{O}\right.$ gas) (Robie et al. 1978).

${ }^{\mathrm{d}}$ Calculated for the anhydrous apatite phases, considering the hydration water as thermodynamically equivalent to liquid water as was done previously.

TABLE 4. Thermodynamic cycle for calculating the enthalpies of formation from the oxides of $\mathrm{Ln}$-doped apatite samples based on mechanism 4, with $\mathrm{Ln}=\mathrm{Eu}, \mathrm{Er}, \mathrm{Nd}$, and Tb

\begin{tabular}{lc}
\hline Reaction & \\
\hline $\mathrm{Ln}_{2} \mathrm{O}_{3}(\mathrm{~s}, 298 \mathrm{~K}) \rightarrow \mathrm{Ln}_{2} \mathrm{O}_{3}(\mathrm{sol}, 973 \mathrm{~K})$ & $\Delta H$ \\
$\mathrm{CaO}(\mathrm{s}, 298 \mathrm{~K}) \rightarrow \mathrm{CaO}($ sol, $973 \mathrm{~K})$ & $\Delta H_{\mathrm{ds}}\left(\mathrm{Ln}_{2} \mathrm{O}_{3}\right)$ \\
$\mathrm{P}_{2} \mathrm{O}_{5}(\mathrm{~s}, 298 \mathrm{~K}) \rightarrow \mathrm{P}_{2} \mathrm{O}_{5}(\mathrm{sol}, 973 \mathrm{~K})$ & $\Delta H_{\mathrm{ds}}(\mathrm{CaO})$ \\
$\mathrm{H}_{2} \mathrm{O}(\mathrm{l}, 298 \mathrm{~K}) \rightarrow \mathrm{H}_{2} \mathrm{O}(\mathrm{g}, 973 \mathrm{~K})$ & $\Delta H_{\mathrm{ds}}\left(\mathrm{P}_{2} \mathrm{O}_{5}\right)^{\mathrm{b}}$ \\
$\mathrm{Ca}_{10-\mathrm{x}-\mathrm{y}} \mathrm{Ln}_{\mathrm{y}}\left(\mathrm{PO}_{4}\right)_{6-\mathrm{x}}\left(\mathrm{HPO}_{4}\right)_{\mathrm{x}}(\mathrm{OH})_{2-\mathrm{x}-\mathrm{y}} \mathrm{O}_{\mathrm{y}}\left(\mathrm{H}_{2} \mathrm{O}\right)_{\mathrm{n}}(\mathrm{s}, 298 \mathrm{~K}) \rightarrow(10-\mathrm{x}-\mathrm{y}) \mathrm{CaO}(\mathrm{sol}, 973 \mathrm{~K})+(\mathrm{y} / 2)$ \\
$\mathrm{Ln}_{2} \mathrm{O}_{3}(\mathrm{sol}, 973 \mathrm{~K})+3 \mathrm{P}_{2} \mathrm{O}_{5}(\mathrm{sol}, 973 \mathrm{~K})+(1-\mathrm{y} / 2+\mathrm{n}) \mathrm{H}_{2} \mathrm{O}(\mathrm{g}, 973 \mathrm{~K})$ & $\Delta H_{\mathrm{ds}}(\mathrm{Ln}$-apatite $)$
\end{tabular}

Formation reaction from the oxides:

$(10-x-y) C a O(s, 298 K)+(y / 2) \mathrm{Ln}_{2} \mathrm{O}_{3}(s, 298 \mathrm{~K})+3 \mathrm{P}_{2} \mathrm{O}_{5}(\mathrm{~s}, 298 \mathrm{~K})+(1-\mathrm{y} / 2+\mathrm{n}) \mathrm{H}_{2} \mathrm{O}(\mathrm{l}, 298 \mathrm{~K})$

$\rightarrow \mathrm{Ca}_{10-x-\mathrm{y}} \mathrm{Ln}_{\mathrm{y}}\left(\mathrm{PO}_{4}\right)_{6-\mathrm{x}}\left(\mathrm{HPO}_{4}\right)_{x}(\mathrm{OH})_{2-\mathrm{x}-\mathrm{y}} \mathrm{O}_{\mathrm{y}}\left(\mathrm{H}_{2} \mathrm{O}\right)_{\mathrm{n}}(\mathrm{s}, 298 \mathrm{~K}) \quad \Delta H_{\mathrm{f}, \mathrm{x}}^{\circ}(\mathrm{Ln}$-apatite $)$

Therefore:

$\Delta H_{\mathrm{fox}}^{\circ}(\mathrm{Ln}$-apatite $)=(10-\mathrm{x}-\mathrm{y}) \Delta H_{\mathrm{ds}}(\mathrm{CaO})+(\mathrm{y} / 2) \Delta H_{\mathrm{ds}}\left(\mathrm{Ln}_{2} \mathrm{O}_{3}\right)+3 \Delta H_{\mathrm{ds}}\left(\mathrm{P}_{2} \mathrm{O}_{5}\right)+(1-\mathrm{y} / 2$ $+\mathrm{n}) \Delta H_{\mathrm{ds}}\left(\mathrm{H}_{2} \mathrm{O}\right)$

${ }^{\mathrm{a}} \mathrm{s}=$ solid, $\mathrm{I}=$ liquid, $\mathrm{g}=$ gas, and sol = solution.

b Ushakov et al. (2001).

point, the enthalpy of drop solution for $\mathrm{Eu}(\mathrm{OH})_{3}$ was determined experimentally using a reference $\mathrm{Eu}(\mathrm{OH})_{3}$ sample precipitated in this work (see experimental section). This experimental value of $\Delta H_{\mathrm{ds}}$ for $\mathrm{Eu}(\mathrm{OH})_{3}$ was then measured by drop solution calorimetry. Interestingly, this experimental value was found to be very close (within $2 \mathrm{~kJ} / \mathrm{mol}$, see Table 3 ) to the $\Delta H_{\mathrm{ds}}$ value calculated using available thermodynamic data (i.e., using data for $\mathrm{Eu}_{2} \mathrm{O}_{3}$ and $\mathrm{H}_{2} \mathrm{O}$, see footnote " $\mathrm{c}$ " in Table 3). Considering this closeness between the calculated and experimental values for $\mathrm{Eu}(\mathrm{OH})_{3}$, and the potential difficulty to prepare pure $\mathrm{Ln}(\mathrm{OH})_{3}$ phases, it was thus decided for the other lanthanide hydroxides to use enthalpies of drop solution (Table 3) calculated from values of the drop solution enthalpy of $\mathrm{Ln}_{2} \mathrm{O}_{3}$ and the formation enthalpy of $\mathrm{Ln}(\mathrm{OH})_{3}$ from $\mathrm{Ln}_{2} \mathrm{O}_{3}+\mathrm{H}_{2} \mathrm{O}$.

The enthalpies of formation of the apatitic phase alone [i.e., after removal of the $\mathrm{Ln}(\mathrm{OH})_{3}$ contribution], from the constituent oxides at $25^{\circ} \mathrm{C}\left(\Delta H_{\mathrm{f}, \mathrm{ox}}\right)$ using the thermodynamic cycle in Table 4, have been added to Table 3. Calculating enthalpies of formation from constituent binary oxides is particularly relevant as these values relate directly to the experimentally measured heats of drop solution, thus limiting the propagation of errors. The strongly exothermic values obtained for all studied systems indicate their significant stability with respect to the corresponding binary oxides. As discussed above, for low $\mathrm{Ln}^{3+}$ concentrations (y $\leq 0.02$ ), all four $\mathrm{Ca}^{2+} / \mathrm{Ln}^{3+}$ substitution mechanisms theoretically remain possible. Accordingly, the calculated $\Delta H_{\mathrm{f}, \mathrm{ox}}$ values may somewhat fluctuate depending on the substitution mechanism, but we estimated this fluctuation to a maximum of $1.05 \%$ around the values calculated here from mechanism 4 . This confirms that enthalpy values calculated according to mechanism 4 are, from a practical viewpoint, fully relevant for evaluating the heats of formation of Ln-doped apatites. However, it also indicates that it is not possible here to determine the most favorable mechanism at low concentration from an energetic standpoint.

Figure 3 gives a graphical view of the variation, for each lanthanide ion, of $\Delta H_{\mathrm{f}, \mathrm{ox}}^{\circ}$ vs. the experimental $\mathrm{Ln} /(\mathrm{Ca}+\mathrm{Ln})$ molar ratio in the apatite. In each series, substituting lanthanide cations for calcium was found to significantly affect the energetics of the resulting apatite phase. The formation enthalpy becomes less exothermic upon increasing the dopant concentration. These findings point out the general tendency of $\mathrm{Ln}^{3+}$ incorporation to destabilize the (hydroxy)apatite system. These changes are likely due to charge and/or size mismatch between the dopant $\left(\mathrm{Ln}^{3+}\right)$ and host $\left(\mathrm{Ca}^{2+}\right)$ cations and the corresponding charge balancing mechanism, here calculated as the creation of oxygen vacancies (mechanism 4). As shown in Figure 3, at low concentration of dopant, enthalpies of formation become less exothermic through an approximately linear relationship with dopant concentration. However, at higher concentrations, the enthalpies of formation tend to stabilize, indicating that we approach the solubility limit of incorporation of lanthanide in these systems.

To illustrate the effect of $\mathrm{Ln}^{3+}$ ionic size on energetics, the difference in formation enthalpies between doped and undoped systems was plotted against the dopant ionic radius, $r_{\mathrm{Ln}^{3+}}$. Figure 4 reports the case of the experimental dopant concentration $\mathrm{y}=$ 0.04 . This figure suggests that as the ionic radius of the dopant increases, the formation enthalpy tends to become less exothermic, 

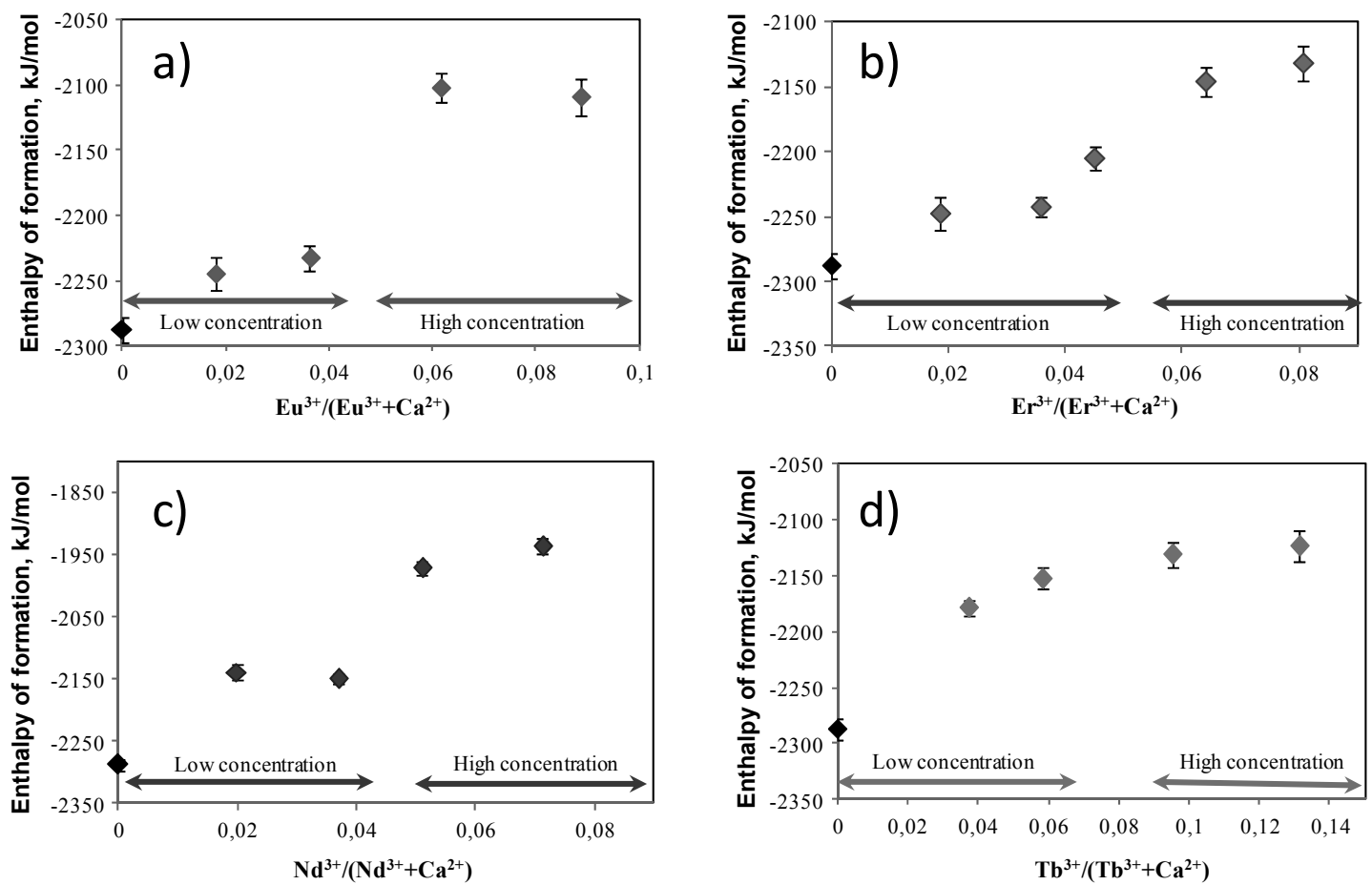

FIGURE 3. Enthalpies of formation $\Delta H_{\mathrm{f}, \mathrm{ox}}^{\circ}$ of $\mathrm{Ln}$-doped apatites vs. $\mathrm{Ln} /(\mathrm{Ln}+\mathrm{Ca})$ molar ratio. The undoped sample is shown on each graph in black. (a) Eu-doped samples, (b) Er-doped samples, (c) Nd-doped samples, and (d) Tb-doped samples.

indicating as a general tendency, a greater destabilizing effect for the larger lanthanide cations. However, this general trend is only approximate, taking into account the dispersion of the data points (e.g., Tb and Eu points are close to one another despite different radii). Thus ionic radius may not be the sole parameter in the variation of $\Delta H_{\mathrm{f}}^{\circ}$, and other factors such as electronegativity or polarizability may play a role. Differences in maturation state, discussed further below, may also affect the energetics.

Enthalpies of formation $\Delta H_{\mathrm{f}, \mathrm{el}}^{\circ}$ (at $25^{\circ} \mathrm{C}$ ) from the elements in their standard states have also been calculated (Table 3). The value $-13307.5 \pm 12.4 \mathrm{~kJ} / \mathrm{mol}$ obtained for the undoped apatite, which is slightly nonstoichiometric as compared to $\mathrm{Ca}_{10}\left(\mathrm{PO}_{4}\right)_{6}(\mathrm{OH})_{2}$, is slightly less exothermic than with the value measured previously for stoichiometric HA $(-13431.0 \pm 22.7$ $\mathrm{kJ} / \mathrm{mol}$ ) (Rollin-Martinet et al. 2013). As expected, the general variation of $\Delta H_{\mathrm{f}, \mathrm{e}}^{\circ}$ for a given $\mathrm{Ln}^{3+}$ ion follows the same trend as evidenced above for $\Delta H_{\mathrm{f}, \mathrm{ox}}^{\circ}$, being less exothermic for increasing $\mathrm{Ln}^{3+}$ dopant content. Despite low amounts of incorporated $\mathrm{Ln}^{3+}$ cations, reaching about $10 \%$ of the full cationic content, the destabilizing effect is quite significant, with a variation in enthalpy as compared to the undoped samples up to ca. $8 \%$. This substantial destabilizing effect may possibly explain, at least in part, the low solubility limit of $\mathrm{Ln}^{3+}$ ions in the solid solution.

In the case of apatites, the relative stability can generally be assessed on the basis of enthalpy considerations, since the entropy contribution $\left(T \Delta S_{\mathrm{f}}^{\circ}\right)$ in Gibbs free energies of formation $\left(\Delta G_{\mathrm{f}}^{\circ}\right)$ remains low for such systems (Rollin-Martinet et al. 2013). However, it is interesting to evaluate the Gibbs free energies of formation $\Delta G_{\mathrm{f}}^{\circ}$ of these apatite compounds, which represent the "actual" stability parameters to take into account in thermodynamic calculations. To that aim, it was first necessary to estimate standard entropies $S^{\circ}$. First approximations of $S^{\circ}$ were calculated by considering equilibrium reactions involving only solid phases (namely in this case calcium and lanthanide oxides or hydroxides), such as:

$(9-\mathrm{x}-\mathrm{y} / 2) \mathrm{CaO}(\mathrm{s}, 298 \mathrm{~K})+(\mathrm{y} / 2) \mathrm{Ln}_{2} \mathrm{O}_{3}(\mathrm{~s}, 298 \mathrm{~K})+3 \mathrm{P}_{2} \mathrm{O}_{5}$ $(\mathrm{s}, 298 \mathrm{~K})+(1-\mathrm{y} / 2) \mathrm{Ca}(\mathrm{OH})_{2}(\mathrm{~s}, 298 \mathrm{~K}) \rightarrow$

$\mathrm{Ca}_{10-x-y} \mathrm{Ln}_{y}\left(\mathrm{PO}_{4}\right)_{6-x}\left(\mathrm{HPO}_{4}\right)_{x}(\mathrm{OH})_{2-x-y} \mathrm{O}_{y}$

Based on entropy values tabulated in thermodynamic databases for these oxide/hydroxide species and for the elements in their standard states, it was then possible to evaluate the $S^{\circ}, \Delta S_{\mathrm{f}}^{\circ}$, and then $\Delta G_{\mathrm{f}}^{\circ}$ for the apatite samples prepared in this work. The values are reported in Table 5. As expected, $\Delta G_{\mathrm{f}}^{\circ}$ is again found to be mostly enthalpy-driven, with only a minor contribution of entropy.

\section{IMPLICATIONS OF LN-DOPING ON THE STABILITY OF APATITE COMPOUNDS}

Based on such evaluations of $\Delta G_{\mathrm{f}}^{\circ}$, it now becomes possible to investigate the effect of Ln doping on the stability of apatite and to estimate, for example, equilibrium constants for dissolution and partitioning reactions involving aqueous media.

Our characterization results (see above) clearly indicated that $\mathrm{Ln}^{3+}=\mathrm{Eu}^{3+}, \mathrm{Er}^{3+}, \mathrm{Nd}^{3+}$, and $\mathrm{Tb}^{3+}$ ions acted as apatite growth inhibitors. Therefore, Ln-doped apatites obtained via a given set of experimental conditions will necessarily be less mature (i.e., 


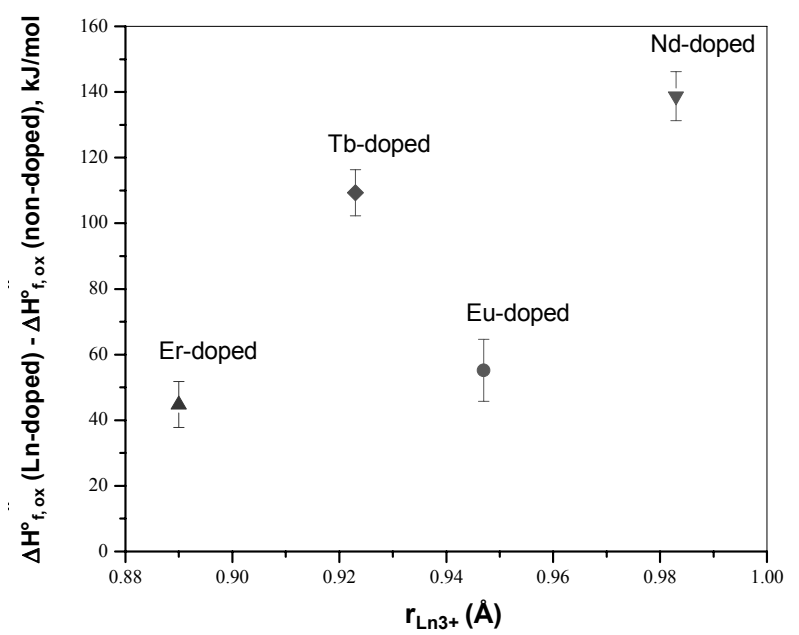

FIGURE 4. Difference between enthalpies of formation of doped and undoped samples vs. dopant radius for $\mathrm{Ca}_{10-\mathrm{x}-\mathrm{y}} \mathrm{Ln}_{\mathrm{y}}\left(\mathrm{PO}_{4}\right)_{6-\mathrm{x}}\left(\mathrm{HPO}_{4}\right)_{\mathrm{x}}$ $(\mathrm{OH})_{2-\mathrm{x}-\mathrm{y}} \mathrm{O}_{\mathrm{y}} \cdot \mathrm{nH}_{2} \mathrm{O}(\mathrm{Ln}=\mathrm{Eu}, \mathrm{Er}, \mathrm{Nd}$, and $\mathrm{Tb})$ for an experimental dopant content of $\mathrm{y}=0.04$.

TABLE 5. Evaluated thermodynamic properties of formation, from the elements (at $298 \mathrm{~K}$ ), for the undoped and $\mathrm{Ln}$-doped $(\mathrm{Ln}=\mathrm{Eu}$, $\mathrm{Er}, \mathrm{Nd}, \mathrm{Tb}$ ) apatites prepared in this work

\begin{tabular}{lcccc}
\hline $\begin{array}{l}\text { Apatite } \\
\text { samples }\end{array}$ & $\begin{array}{c}\Delta H_{\mathrm{fel}}^{\circ} \\
(\mathrm{kJ} / \mathrm{mol})\end{array}$ & $\begin{array}{c}S^{\circ} \\
{[\mathrm{J} /(\mathrm{mol} \cdot \mathrm{K})]}\end{array}$ & $\begin{array}{c}\Delta S_{\mathrm{fel}}^{\circ} \\
{[\mathrm{J} /(\mathrm{mol} \cdot \mathrm{K})]}\end{array}$ & $\begin{array}{c}\Delta G_{\mathrm{fel}}^{\circ} \\
(\mathrm{kJ} / \mathrm{mol})\end{array}$ \\
\hline CaP & $-13307.5 \pm 12.4$ & $772 \pm 9$ & $-2682 \pm 9$ & $-12508.2 \pm 13.4$ \\
CaEuP1 & $-13173.1 \pm 14.9$ & $768 \pm 10$ & $-2659 \pm 10$ & $-12380.7 \pm 15.8$ \\
CaEuP4 & $-12894.1 \pm 12.7$ & $754 \pm 10$ & $-2607 \pm 10$ & $-12117.2 \pm 13.8$ \\
CaEuP7 & $-12481.6 \pm 14.3$ & $739 \pm 10$ & $-2550 \pm 10$ & $-11721.7 \pm 15.3$ \\
CaEuP10 & $-12474.7 \pm 16.8$ & $740 \pm 10$ & $-2536 \pm 10$ & $-11719.0 \pm 17.8$ \\
CaErP1 & $-13184.2 \pm 14.7$ & $768 \pm 9$ & $-2654 \pm 9$ & $-12393.3 \pm 15.6$ \\
CaErP2 & $-13139.1 \pm 10.5$ & $767 \pm 9$ & $-2634 \pm 9$ & $-12354.2 \pm 11.7$ \\
CaErP4 & $-13038.4 \pm 12.2$ & $764 \pm 9$ & $-2617 \pm 9$ & $-12258.6 \pm 13.3$ \\
CaErP7 & $-12882.9 \pm 13.7$ & $759 \pm 9$ & $-2592 \pm 9$ & $-12110.4 \pm 14.6$ \\
CaErP10 & $-12627.4 \pm 16.0$ & $746 \pm 9$ & $-2538 \pm 9$ & $-11871.1 \pm 16.8$ \\
CaNdP1 & $-13024.5 \pm 14.8$ & $766 \pm 9$ & $-2646 \pm 10$ & $-12236.0 \pm 15.7$ \\
CaNdP2 & $-12958.9 \pm 10.8$ & $763 \pm 10$ & $-2621 \pm 10$ & $-12177.9 \pm 12.0$ \\
CaNdP7 & $-12439.3 \pm 13.6$ & $744 \pm 10$ & $-2556 \pm 10$ & $-11677.6 \pm 14.7$ \\
CaNdP10 & $-12259.8 \pm 14.4$ & $737 \pm 10$ & $-2519 \pm 10$ & $-11509.2 \pm 15.5$ \\
CaTbP2 & $-13025.3 \pm 11.0$ & $765 \pm 10$ & $-2626 \pm 10$ & $-12242.7 \pm 12.2$ \\
CaTbP4 & $-12746.4 \pm 12.9$ & $751 \pm 10$ & $-2570 \pm 10$ & $-11980.5 \pm 13.9$ \\
CaTbP7 & $-12965.9 \pm 14.7$ & $769 \pm 10$ & $-2582 \pm 10$ & $-12196.5 \pm 15.6$ \\
CaTbP10 & $-13109.5 \pm 17.2$ & $781 \pm 10$ & $-2580 \pm 10$ & $-12340.7 \pm 18.1$ \\
\hline & & & &
\end{tabular}

exhibiting in particular a composition farther from stoichiometry) than apatites obtained in similar conditions but in the absence of $\mathrm{Ln}^{3+}$ ions in the medium. In this context, the comparison of doped and undoped samples becomes more delicate, as the maturation state of both the doped and undoped sample has to be taken into account.

The incorporation during synthesis of $\mathrm{Ln}^{3+}$ ions into the apatite lattice does not "simply" have a substituting role, it also influences the final structure and particle size state reached. Two phenomena have to be distinguished: (1) the ionic substitution itself and (2) the lower maturity of the apatite phase containing Ln. If one considers (when comparing doped and undoped apatites) a common degree of maturity, then the two phenomena might be separable. But this remains a hypothetical situation. In real conditions, when the precipitation takes place in the presence of $\mathrm{Ln}^{3+}$ ions, the final apatite obtained exhibits a lower crystallinity state, higher nonstoichiometry, smaller particle size, and poorer crystallinity. Consequently, if one intends to evaluate exclusively the energetic effect due solely to the incorporation in apatite of $\mathrm{Ln}^{3+}$ ions, the initial apatite system to consider in the reaction scheme (as illustrated in Eq. 2 for mechanism 4) should be a phase with equivalent maturation state: This is very difficult to attain.

$$
\begin{gathered}
\mathrm{Ca}_{10-\mathrm{x}}\left(\mathrm{PO}_{4}\right)_{6-\mathrm{x}}\left(\mathrm{HPO}_{4}\right)_{\mathrm{x}}(\mathrm{OH})_{2-\mathrm{x}}+\mathrm{yLn}_{(\mathrm{aq})}^{3+}+\mathrm{yOH}_{(\mathrm{aq})}^{-} \leftrightarrow \\
\mathrm{Ca}_{10-\mathrm{x}-\mathrm{y}} \mathrm{Ln}_{\mathrm{y}}\left(\mathrm{PO}_{4}\right)_{6-\mathrm{x}}\left(\mathrm{HPO}_{4}\right)_{\mathrm{x}}(\mathrm{OH})_{2-\mathrm{x}-\mathrm{y}} \mathrm{O}_{\mathrm{y}}+\mathrm{yCa}_{(\text {(aq) }}^{2+}+\mathrm{yH}_{2} \mathrm{O}_{(\mathrm{liq})}
\end{gathered}
$$

With the view to evaluate the variation in free energy accompanying Equation $2\left[\Delta G_{\text {react }}=\Delta G_{\text {react }}^{\circ}+\mathrm{R} T \operatorname{Ln}\left(K_{\text {eq }}\right)\right]$, it is thus not possible to use as initial apatite state the undoped compound prepared in this work (which exhibits a more advanced maturation stage). On the other hand, we have recently published data relative to the energetics of calcium phosphate apatites with various degrees of maturation (Rollin-Martinet et al. 2013). This allowed us to evaluate $\Delta G_{\text {react }}^{\circ}$ and $K_{\text {eq }}$ (equilibrium constant at $25^{\circ} \mathrm{C}$ ) for systems presenting similar maturation patterns. For experimental Ln doping rates between 5 and $9 \%$, $\Delta G_{\text {react }}^{\circ}$ values (not counting numbers lower than their propagated errors) were found between $-62 \pm 18$ and $-377 \pm 19 \mathrm{~kJ} / \mathrm{mol}$; and the corresponding values of $p K_{\mathrm{eq}}$ were found between -11 \pm 7 and $-66 \pm 8$. No clear ranking tendency was detectable in terms of $\Delta G_{\mathrm{f}}^{\circ}$ or $K_{\text {eq }}$ values so as to distinguish the behavior of the four lanthanides studied in this work. However, these negative values point to a situation where $\mathrm{Ln}^{3+}$ incorporation (at least for the four lanthanides considered here) is energetically favorable - considering a constant maturation state - meaning that Equation 2 has a spontaneous tendency to evolve from left to right. It may be remarked that Equation 2 unveils a $\mathrm{pH}$ dependency through the involvement of $\mathrm{OH}^{-}$ions. Considering ideal solid phases and water solvent (activities equal to unity), the equilibrium constant $K_{\text {eq }}$ can thus be expressed as a function of ionic activities (shown by parentheses) as follows:

$$
p K_{\mathrm{eq}}=-y \cdot \log \frac{\left(\mathrm{Ca}^{2+}\right)}{\left(\mathrm{Ln}^{3+}\right)}+y \cdot(\mathrm{pH}-14)
$$

Considering, as an illustrative example, a $\mathrm{pH}$ value of 9 and $\mathrm{y}=0.5$, Equation 3 would lead at $25^{\circ} \mathrm{C}$ to a $\left(\mathrm{Ca}^{2+}\right) /\left(\mathrm{Ln}^{3+}\right)$ ratio typically ranging between $17 \pm 10$ and $127 \pm 11$, indicating a $\mathrm{Ca}^{2+}$ activity that is 1 or 2 orders of magnitude greater than that of $\mathrm{Ln}^{3+}$.

Therefore, this work has shown, on a quantitative basis for the first time, that lanthanide ions $\left(\mathrm{Ln}^{3+}\right)$ can be accommodated in apatite with only small energetic destabilization of the solid phase. The thermochemical data reported in this work can be used to calculate the partitioning of Ln between apatite, fluids, melts, and other minerals. Such understanding of Ln distributions is relevant to various fields including petrology, geochemistry, Ln mining and processing, Ln transport in the environment, nanomedicine (use of Ln as phosphors in apatite in medical diagnostics) or else anthropology (diagenesis of skeletal remains).

\section{ACKNOWLEDGMENTS}

This work was supported by the International Center of Materials Research (ICMR), the National Polytechnical Institute of Toulouse (INPT) and the FranceBerkeley Fund (2008 call). 


\section{REFERENCES CITED}

Al-Kattan, A., Dufour, P., Dexpert-Ghys, J., and Drouet, C. (2010a) Preparation and physicochemical characteristics of luminescent apatite-based colloids. Journal of Physical Chemistry C, 114, 2918-2924.

Al-Kattan, A., Errassifi, F., Sautereau, A., Sarda, S., Dufour, P., Barroug, A., Dos Santos, I., Combes, C., Grossin, D., Rey, C., and Drouet, C. (2010b) Medical potentialities of biomimetic apatites through adsorption, ionic substitution, and mineral/organic associations: Three illustrative examples. Advanced Engineering Materials, 12, B224-B233.

Al-Kattan, A., Dufour, P., and Drouet, C. (2011) Purification of biomimetic apatitebased hybrid colloids intended for biomedical applications: A dialysis study. Colloids and Surface B-Biointerfaces, 82, 378-384.

Al-Kattan, A., Girod-Fullana, S., Charvillat, C., Ternet-Fontebasso, H., Dufour, P., Dexpert-Ghys, J., Santran, V., Bordere, J., Pipy, B., Bernad, J., and Drouet, C. (2012) Biomimetic nanocrystalline apatites: Emerging perspectives in cancer diagnosis and treatment. International Journal of Pharmaceutics, 423, 26-36.

Al-Kattan, A., Santran, V., Dufour, P., Dexpert-Ghys, J., and Drouet, C. (2014) Novel contributions on luminescent apatite-based colloids intended for medical imaging. Journal of Biomaterials Applications, 28, 697-707.

Barroug, A., and Glimcher, M.J. (2002) Hydroxyapatite crystals as a local delivery system for cisplatin: adsorption and release of cisplatin in vitro. Journal of Orthopaedic Research, 20, 274-280.

Benaziz, L., Barroug, A., Legrouri, A., Rey, C., and Lebugle, A. (2001) Adsorption of O-phospho-L-serine and L-serine onto poorly crystalline apatite. Journal of Colloid and Interface Science, 238, 48-53.

Bohner, M., Brunner, T.J., and Stark, W.J. (2008) Controlling the reactivity of calcium phosphate cements. Journal of Materials Chemistry, 18, 5669-5675.

Bouladjine, A., Al-Kattan, A., Dufour, P., and Drouet, C. (2009) New advances in nanocrystalline apatite colloids intended for cellular drug delivery. Langmuir, $25,12256-12265$.

Cardoso, D.A., Jansen, J.A., and Leeuwenburgh, S.C.G. (2012) Synthesis and application of nanostructured calcium phosphate ceramics for bone regeneration. Journal of Biomedical Materials Research Part B-Applied Biomaterials, 100B, 2316-2326.

Drouet, C., Carayon, M.-T., Combes, C., and Rey, C. (2005) Exchange of biologically relevant ions on nanocrystalline apatites. Geochimica et Cosmochimica Acta, 69, A69-A69.

(2008) Surface enrichment of biomimetic apatites with biologically-active ions $\mathrm{Mg}^{2+}$ and $\mathrm{Sr}^{2+}$ : A preamble to the activation of bone repair materials. Materials Science and Engineering C, 28, 1544-1550.

Drouet, C., Gomez-Morales, J., Iafisco, M., and Sarda, S. (2012) Calcium phosphate surface tailoring technologies for drug delivering and tissue engineering. In L. Rimondini, C.L. Bianchi, and E. Vernè, Eds., Surface Tailoring of Inorganic Materials for Biomedical Applications 43-111. Bentham Science, e-book.

Eichert, D., Combes, C., Drouet, C., and Rey, C. (2005) Formation and evolution of hydrated surface layers of apatites. Bioceramics, 17, 17, 3-6.

Elliott, J.C. (1994) Structure and Chemistry of the Apatites and Other Calcium Orthophosphates. Elsevier Science, Amsterdam.

Gomez-Morales, J., Iafisco, M., Manuel Delgado-Lopez, J., Sarda, S., and Drouet, C. (2013) Progress on the preparation of nanocrystalline apatites and surface characterization: Overview of fundamental and applied aspects. Progress in Crystal Growth and Characterization of Materials, 59, 1-46.

Grunenwald, A., Keyser, C., Sautereau, A.M., Crubezy, E., Ludes, B., and Drouet, C. (2014) Adsorption of DNA on biomimetic apatites: Toward the understanding of the role of bone and tooth mineral on the preservation of ancient DNA. Applied Surface Science, 292, 867-875.

Iafisco, M., Varoni, E., Di Foggia, M., Pietronave, S., Fini, M., Roveri, N., Rimondini, L., and Prat, M. (2012) Conjugation of hydroxyapatite nanocrystals with human immunoglobulin $\mathrm{G}$ for nanomedical applications. Colloids and Surfaces B-Biointerfaces, 90, 1-7.

Jemal, M. (2011) Thermochemistry and kinetics of the reactions of apatite phosphates with acid solutions. In M. Tadashi, Ed., Application of Thermodynamics to Biological and Materials Science, p. 547-572. InTech, Rijeka, Croatia.

Kocsis, L., Trueman, C.N., and Palmer, M.R. (2010) Protracted diagenetic alteration of REE contents in fossil bioapatites: Direct evidence from $\mathrm{Lu}-\mathrm{Hf}$ isotope systematics. Geochimica et Cosmochimica Acta, 74, 6077-6092.

Kohn, M.J., Rakovan, J., and Hughes, J.M. (Eds.) (2003) Phosphates: Geochemical, Geobiological, and Materials Importance. Reviews in Mineralogy and Geochemistry, vol. 48, 742 pp. Mineralogical Society of America, Chantilly, Virginia.

Koutsoukos, P.G. (1998) Influence of metal ions on crystal growth of calcium phosphates. In Z. Amjad, Ed., Calcium Phosphates in Biological and Industrial Systems, p. 145-171. Kluwer Academic Publishers, Boston.

Martin, P., Carlot, G., Chevarier, A., Den-Auwer, C., and Panczer, G. (1999) Mechanisms involved in thermal diffusion of rare earth elements in apatite. Journal of Nuclear Materials, 275, 268-276.

Mondejar, S.P., Kovtun, A., and Epple, M. (2007) Lanthanide-doped calcium phosphate nanoparticles with high internal crystallinity and with a shell of
DNA as fluorescent probes in cell experiments. Journal of Materials Chemistry, 17, 4153-4159.

Nagasawa, H. (1970) Rare earth concentrations in zircons and apatites and their host dacites and granites. Earth and Planetary Science Letters, 9, 359-364.

Navrotsky, A. (1977) Progress and new directions in high temperature calorimetry. Physics and Chemistry of Minerals, 2, 89-104.

- (1997) Progress and new directions in high temperature calorimetry revisited. Physics and Chemistry of Minerals, 24, 222-241.

Piriou, B., Fahmi, D., Dexpertghys, J., Taitai, A., and Lacout, J.L. (1987) Unusual fluorescent properties of $\mathrm{Eu}^{3+}$ in oxyapatites. Journal of Luminescence, 39, 97-103.

Prabakaran, K., Balamurugan, A., and Rajeswari, S. (2005) Development of calcium phosphate based apatite from hen's eggshell. Bulletin of Materials Science, 28, 115-119.

Rabadjieva, D., Gergulova, R., Titorenkova, R., Tepavitcharova, S., Dyulgerova, E. Balarew, C., and Petrov, O. (2010) Biomimetic transformations of amorphous calcium phosphate: Kinetic and thermodynamic studies. Journal of Materials Science: Materials in Medicine, 21, 2501-2509.

Rey, C., Combes, C., Drouet, C., Lebugle, A., Sfihi, H., and Barroug, A. (2007a) Nanocrystalline apatites in biological systems: Characterisation, structure and properties. Materialwissenschaft und Werkstofftechnik, 38, 996-1002.

Rey, C., Combes, C., Drouet, C., Sfihi, H., and Barroug, A. (2007b) Physicochemical properties of nanocrystalline apatites: Implications for biominerals and biomaterials. Materials Science and Engineering C, 27, 198-205.

Rey, C., Combes, C., Christophe, D., and Grossin, D. (2011) Bioactive ceramics: Physical chemistry. In P. Ducheyne, K.E. Healy, D.W. Hutmacher, D.W. Grainger, and C.J. Kirkpatrick, Eds., Comprehensive Biomaterials, p. 187-221. Elsevier, Amsterdam

Reynard, B., Lecuyer, C., and Grandjean, P. (1999) Crystal-chemical controls on rare-earth element concentrations in fossil biogenic apatites and implications for paleoenvironmental reconstructions. Chemical Geology, 155, 233-241.

Robie, R.A., Hemingway, B.S., and Fisher, J.R. (1978) Thermodynamic properties of minerals and related substances at $298.15 \mathrm{~K}$ and 1 Bar (105 Pascals) pressure and at higher temperatures. U.S. Geological Survey Bulletin 1452, U.S. Government Printing Office, Washington, D.C., 456 p.

Rodriguez-Lorenzo, L.M., and Gross, K.A. (2003) Encapsulation of apatite particles for improvement in bone regeneration. Journal of Materials Science: Materials in Medicine, 14, 939-943.

Rollin-Martinet, S., Navrotsky, A., Champion, E., Grossin, D., and Drouet, C. (2013) Thermodynamic basis for evolution of apatite in calcified tissues American Mineralogist, 98, 2037-2045.

Spear, F.S., and Pyle, J.M. (2002) Apatite, monazite, and xenotime in metamorphic rocks. Phosphates: Geochemical, Geobiological, and Materials Importance, Reviews in Mineralogy and Geochemistry, 48, 293-335.

Taitai, A., and Lacout, J.L. (1987) Hydroxylation and fluorination of europium containing oxyapatites. Journal of Physics and Chemistry of Solids, 48, 629-633.

Ternane, R., Trabelsi-Ayedi, M., Kbir-Ariguib, N., and Piriou, B. (1999) Luminescent properties of $\mathrm{Eu}^{3+}$ in calcium hydroxyapatite. Journal of Luminescence $81,165-170$.

Trueman, C.N., and Tuross, N. (2002) Trace elements in recent and fossil bone apatite. Phosphates: Geochemical, Geobiological, and Materials Importance, Reviews in Mineralogy and Geochemistry, 48, 489-521.

Tutken, T., Vennemann, T.W., and Pfretzschner, H.U. (2011) Nd and $\mathrm{Sr}$ isotope compositions in modern and fossil bones-Proxies for vertebrate provenance and taphonomy. Geochimica et Cosmochimica Acta, 75, 5951-5970.

Ushakov, S.V., Helean, K.B., Navrotsky, A., and Boatner, L.A. (2001) Thermochemistry of rare-earth orthophosphates. Journal of Materials Research, 16 2623-2633.

Vandecandelaere, N., Rey, C., and Drouet, C. (2012) Biomimetic apatite-based biomaterials: On the critical impact of synthesis and post-synthesis parameters. Journal of Materials Science: Materials in Medicine, 23, 2593-2606.

Verron, E., Khairoun, I., Guicheux, J., and Bouler, J.-M. (2010) Calcium phosphate biomaterials as bone drug delivery systems: A review. Drug Discovery Today, 15, 547-552.

Weber, C., Mueller, M., Vandecandelaere, N., Trick, I., Burger-Kentischer, A., Maucher, T., and Drouet, C. (2013) Enzyme-functionalized biomimetic apatites: Concept and perspectives in view of innovative medical approaches. Journal of Materials Science: Materials in Medicine, 1-12.

Yamashita, K., Owada, H., Nakagawa, H., Umegaki, T., and Kanazawa, T. (1986) Trivalent-cation-substituted calcium oxyhydroxyapatite. Journal of the American Ceramic Society, 69, 590-594.

Yang, P., Quan, Z., Li, C., Kang, X., Lian, H., and Lin, J. (2008) Bioactive, luminescent and mesoporous europium-doped hydroxyapatite as a drug carrier. Biomaterials, 29, 4341-4347. 